\title{
India's Balancing Act to \\ Address Climate Change \\ Under the Paris Agreement
}

Yagyavalk Bhatt, Aljawhara Al Quayid, Nourah Al Hosain and Paul Mollet 


\section{About KAPSARC}

The King Abdullah Petroleum Studies and Research Center (KAPSARC) is a non-profit global institution dedicated to independent research into energy economics, policy, technology and the environment, across all types of energy. KAPSARC's mandate is to advance the understanding of energy challenges and opportunities facing the world today and tomorrow, through unbiased, independent, and high-caliber research for the benefit of society. KAPSARC is located in Riyadh, Saudi Arabia.

\section{Legal Notice}

(C) Copyright 2018 King Abdullah Petroleum Studies and Research Center (KAPSARC). No portion of this document may be reproduced or utilized without the proper attribution to KAPSARC. 


\section{Key Points}

s an emerging economy, a major part of India's nationally determined contribution (NDC) under the Paris Agreement is an emissions intensity target. With its current policies, India is on track to achieve its climate targets under the Agreement. However, the Indian government is balancing a complicated set of domestic priorities and constraints against its wish to be seen as a global leader on climate change. This paper, based on field research in India, outlines the key findings from a set of interviews regarding the implementation and enhancement of India's NDC.

Coal is still the cheapest source of baseload electricity in India and will continue to be its main fuel source for electricity.

India is constrained in its ability to prioritize climate change objectives by the need to expand energy access and for low-cost energy.

India would like to be seen as a leader on climate change, particularly when compared to other emerging economies such as China, whose targets are treated as a benchmark. This wish is balanced against its need to continue its economic expansion.

Fossil fuel carbon dioxide $\left(\mathrm{CO}_{2}\right)$ emissions.

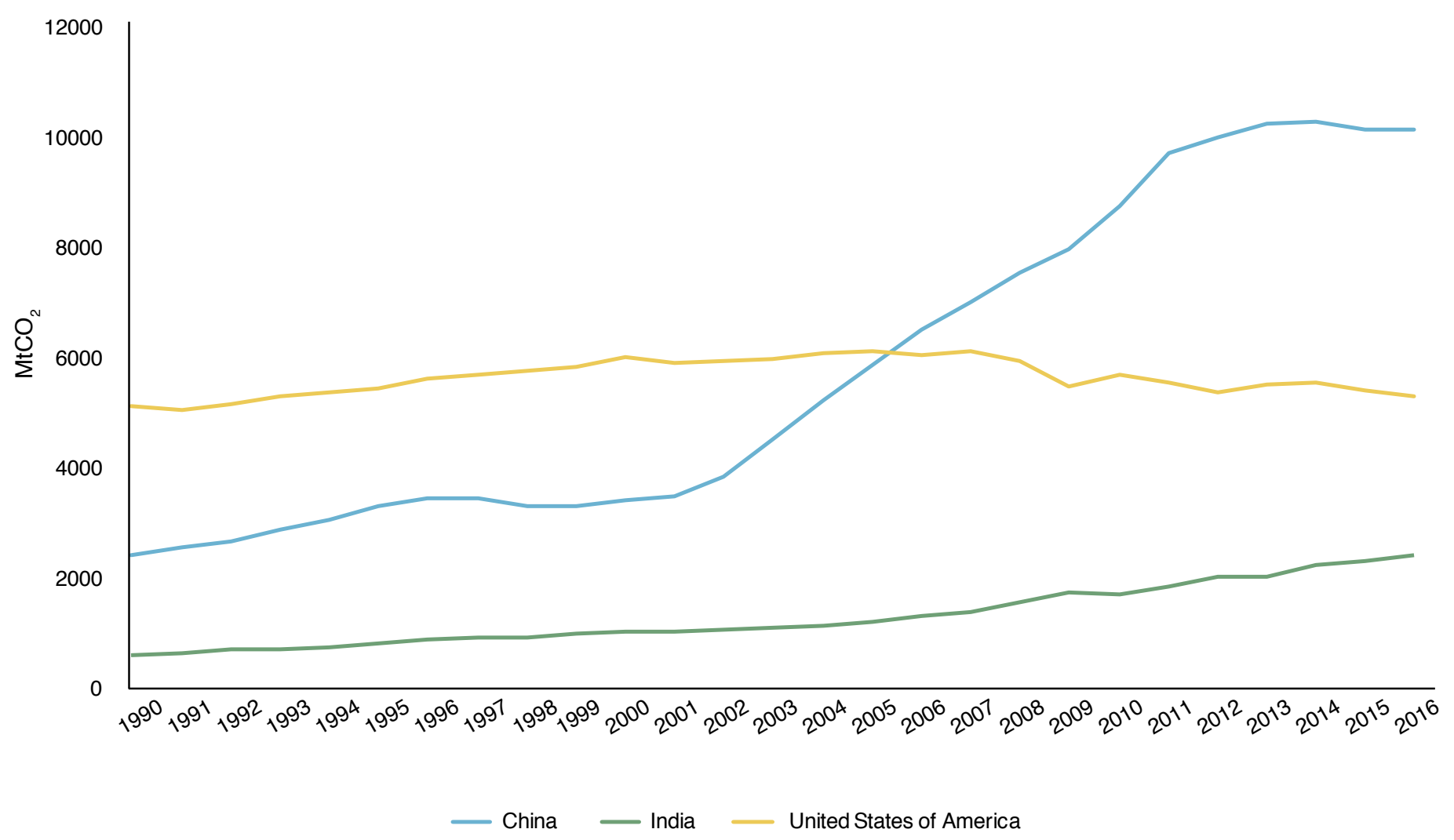

Source: U.S. Department of Energy, KAPSARC analysis. 


\section{Key Points}

India tends to take a conservative approach to international commitments.

The Prime Minister of India has the final say on climate policy matters, but consults with and is advised by a small number of actors in his Council on Climate Change. Think tanks play a major supporting role in climate policymaking. 


\section{Executive Summary}

his paper focuses on India's implementation and enhancements of its commitments under the Paris Agreement. The insights in this paper are derived from a series of interviews with subject matter experts in India.

India is one of the largest economies in the world and, consequently, holds an important position in global climate politics. Despite low levels of historical and per capita emissions, India is the third largest emitter of greenhouse gas emissions. These emissions are expected to increase in line with the country's continued economic growth. Further, Indian climate policies have been shaped around domestic priorities such as poverty, provision of basic services, energy access, energy security and other social and economic issues. Consequently, global climate change is a concern but not a priority.

Currently, India has around 57 percent of installed coal-fired capacity in its electricity mix. This is needed to fuel its rising energy needs. Further, India imports the majority of its crude oil. However, environmental concerns related to air and water pollution will continue to exert pressure on the Indian government to reduce its reliance on coal and crude oil. India, therefore, could benefit from linking its energy security, energy access, and climate change policies.

Under Prime Minister Narendra Modi, the topic of climate change has received growing attention from within the Indian political system. India would like to be seen as a leader on climate change, particularly when compared to China whose targets are treated as a benchmark. Many studies have estimated India to be the country most geographically vulnerable to the impacts of climate change, in terms of both economic and social costs. The Indian government reconstituted the Prime Minister's Council on Climate Change, consisting of relevant ministries and independent officials, to achieve its climate change goals. Think tanks and independent institutions also play major supporting roles in formulating India's nationally determined contribution (NDC) emission targets and act as an advisory group to the prime minister's office. 


\section{Introduction}

ndia is a large and growing economy with annual greenhouse gas (GHG) emissions that put it among the world's top emitters in aggregate. At the same time, because of its large population and high rate of poverty, India is one of the lowest per capita emitting countries. Because of its geography, India is also among the most vulnerable countries to climate impacts. These factors set up a complicated set of trade-offs for Indian policymakers. The Indian government must also consider the country's need for improved energy access and sustained economic growth when developing its approach to emissions.

In recent years, India has shown a growing recognition of the need for policy instruments aimed at addressing climate change. The Government of India released its first National Action Plan on Climate Change in 2008, announcing eight key measures on energy efficiency and renewable energy. In 2009 at the Conference of Parties in Copenhagen, India released a long-term 'nationally appropriate mitigation action' plan to reduce the emissions intensity of its gross domestic product (GDP) by between 20 to 25 percent by 2020 , compared to its 2005 level (Government of India 2010) (Figure 1).

However, many experts believe that the proposed measures fell short. In response to growing doubts, the Indian government presented an intended nationally determined contribution (INDC) under the United Nations Framework Convention on Climate

Figure 1. Fossil fuel carbon dioxide $\left(\mathrm{CO}_{2}\right)$ emissions.

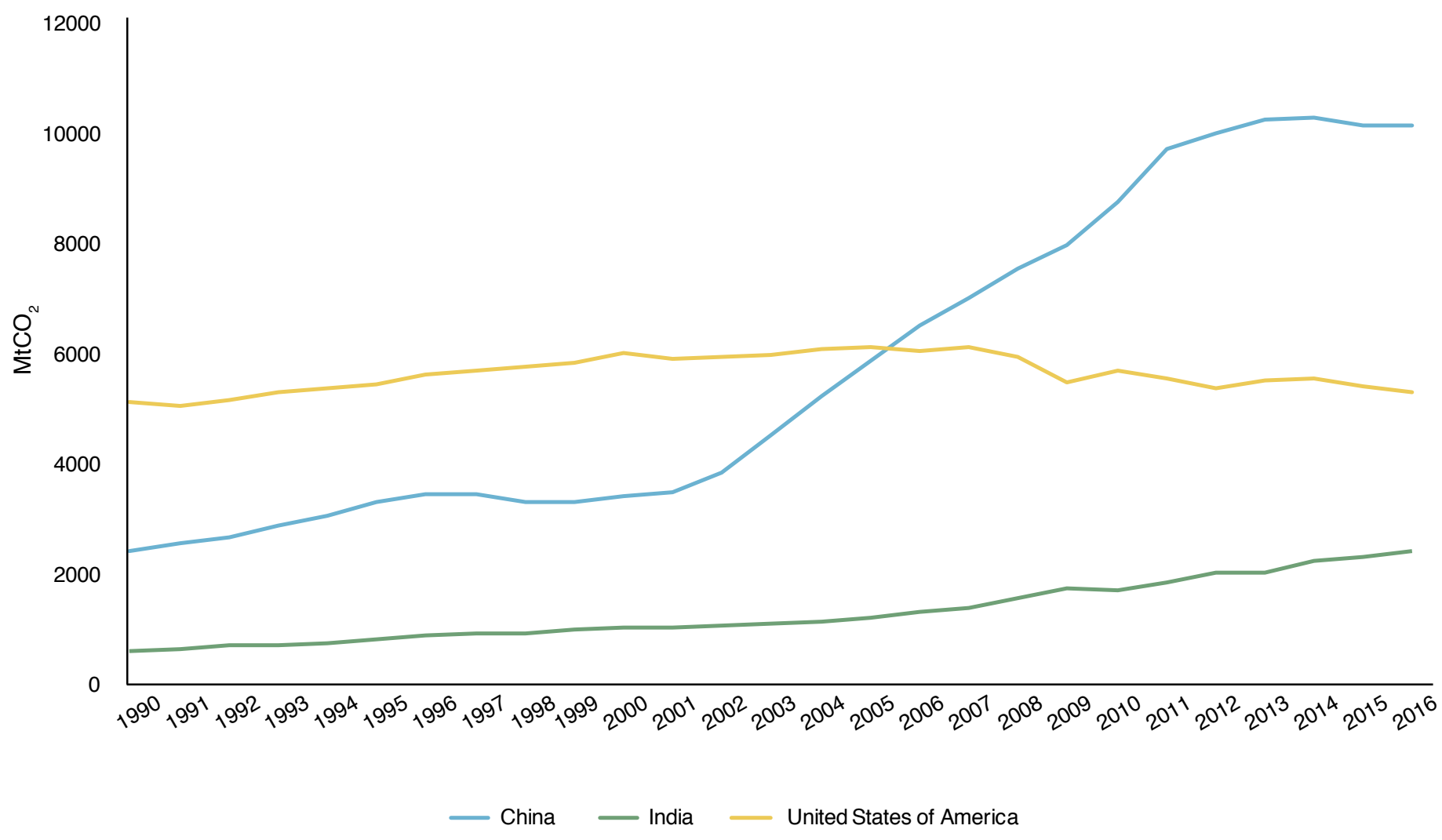

Source: U.S. Department of Energy, KAPSARC analysis. 
Change that revised the previous action plan. In its INDC, India announced its intention to reduce the emissions intensity of its GDP by 33 to 35 percent by 2030 , compared to its 2005 level. The INDC also includes a commitment to install 175 gigawatts (GW) of renewable energy by 2022 , fulfilling its pledge to generate 40 percent of its power from non-fossil fuel sources by 2030 (Government of India 2015). The INDC was ratified on October 2, 2016, becoming India's first nationally determined contribution (NDC) under the Paris Agreement.

India is the world's third largest source of GHG emissions after China and the United States, having emitted 2.4 billion tonnes of carbon dioxide $\left(\mathrm{CO}_{2}\right)$ in 2016. However, on a per capita basis, its $\mathrm{CO}_{2}$ emissions stand at just 1.8 tonnes, well below the world average of 4.2 tonnes (Andrew 2018).

India's emissions are, of course, driven by its fuel mix, with coal as its primary fuel source. India relies on coal as a cheap source of energy to help increase access to electricity among its population and to maximize economic growth. However, India is also highly vulnerable to the impacts of climate change. Various studies have pointed to the growing frequency and intensity of extreme weather events in India that have the potential for significant adverse impacts on people's livelihoods (Ministry of Environment 2010), especially given its population is dependent on agriculture and other climate-sensitive sectors. The need to provide cheap sources of fuel while also combatting climate change creates a significant policy dilemma for the Indian government. 


\section{Background to the Study}

$\mathrm{T}$ his paper is a part of a larger research effort by KAPSARC to assess the political feasibility of implementing and enhancing the NDCs, particularly with respect to emissions. Under the Paris Agreement, the opportunity exists for signatories to enhance their NDCs by 2020 after an ongoing stock-taking process. The collective efforts to limit the rise of global temperatures to 2 degrees Celsius (C) above pre-industrial levels (with some countries aiming for a more ambitious $1.5 \mathrm{C}$ objective) will not only be determined by technical solutions that facilitate the reduction of carbon in energy systems, but also by a combination of domestic political constraints and geopolitical considerations. A shift away from carbon comes with financial costs, and the consequent reshaping of industries is likely to redistribute wealth among Paris signatories. As a result, the incentives to enhance current NDCs, and even to implement those committed to now and in the future, will be fraught with political challenges.

This research project combines quantitative and qualitative methods to provide insights into the limits to and the opportunities presented by the Paris Agreement. It will focus on the domestic politics of emissions and the NDCs for each of the top five emitters: China, the United States, the European Union, India and Russia. The project will also take into account geopolitical factors that play into national decision-making processes on NDCs. The project's methodology combines field research in the form of structured interviews with subject matter experts in each of the five jurisdictions referenced above, capturing a range of views from within India. Data obtained in the interviews is then analyzed using the KAPSARC Toolkit for Behavioral Analysis (KTAB) to simulate collective decision-making processes (CDMPs) and evaluate the range of politicallyacceptable outcomes.
This paper provides an insight into the political feasibility of implementing and enhancing the NDCs, particularly with respect to emissions. It sets the stage for a future paper that will detail the findings of the KTAB simulation of the decision-making process within the Indian government.

To allow candid responses, interviews were conducted with the explicit agreement not to attribute specific answers to individual experts. Experts were also given the opportunity to keep their contributions anonymous. Eleven subject matter experts were interviewed in May 2018 in New Delhi. The experts consulted included individuals from the following entities:

Central Ministry, Government of India

The Energy Research Institute (TERI)

Brookings, India

Observer Research Foundation

Center for Policy Research

Council on Energy, Environment and Water

TERI School of Advanced Studies

This paper consolidates the insights obtained through the expert interviews and is divided into five categories:

The Climate Change Institutional Framework in India

\section{Energy Security}

The Role of Think Tanks

Geopolitics

Social Issues 


\section{The Climate Change Institutional Framework in India}

ndia has a quasi-federal constitutional structure in which legislative and executive powers are allocated between the central government and states. Since his election in 2014, Prime Minister Narendra Modi has established a centralized power structure with direct control over many key portfolios, including access to energy, an issue at the top of the government's agenda. In 2014, early in its term, the government revised India's renewable energy targets up from 20 GW to 175 GW by 2022 . In 2015, India endorsed the Paris Agreement and submitted its first INDC, which was then ratified on October 2, 2016, becoming its first NDC. The
Prime Minister's Council on Climate Change was reconstituted to coordinate national action on assessing, adapting to, and mitigating against climate change. The Council also helps ensure India achieves the targets set out in its NDC. Figure 2 shows the composition of the reconstituted Prime Minister's Council on Climate Change.

The prime minister is the chairman of the Council, with relevant ministries members of the council. The Council also includes representatives of civil society, mainly officially-recognized non-governmental organizations and think tanks. Within the council,

Figure 2. Prime Minister's Council on Climate Change.

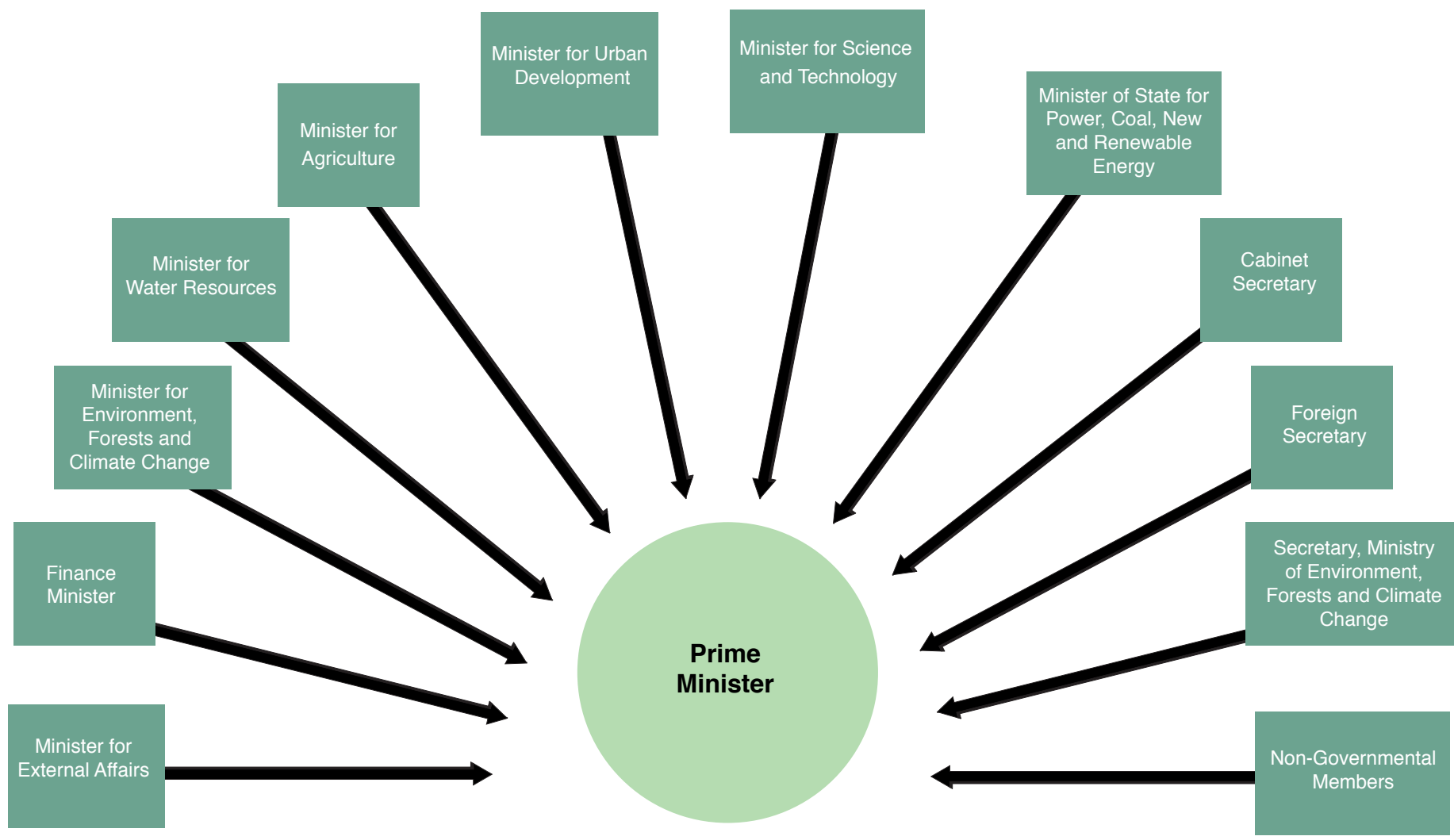

Source: Ministry of Environment, Forests and Climate Change, KAPSARC analysis. 
the Ministry of Environment, Forestry, and Climate Change is the nodal ministry for climate change negotiations. The members of this committee act as advisers to the prime minister, or chairman. Ultimately, the prime minister is the final authority on all issues relating to climate change policy.

As our expert interviews revealed, India is facing a host of pressing developmental and social issues that tend to push climate change down the policy agenda. Formulating NDCs in India happens on a national level. Even though individual states have developed varyingly comprehensive climate action plans, they are not involved in deciding on nationwide climate change targets that make their way into India's NDCs. With a population of 1.3 billion, a large number of whom are below the poverty line and have limited access to electricity, India places more emphasis on human development than climate change. Furthermore, many outside the climate science arena have not been convinced by the link between GHG emissions and immediately relevant phenomena such as extreme weather events and soil erosion, diminishing the perceived importance of climate change policy. While India has been careful not to overcommit in its NDCs, its recently-announced domestic energy policies, such as setting increased renewable energy targets, are already more ambitious than its current NDC.

In his keynote speech at the World Economic Forum in Davos, Switzerland, Narendra Modi spoke of climate change as the greatest threat to society (World Economic Forum 2018). Although the current administration is showing more interest in climate change, it remains low on the country's policy priority list. 


\section{Role of Independent Research Institutes}

$\mathrm{n}$ the absence of in-house government expertise, policymakers are increasingly reliant on think

tanks and independent research institutes that offer advice to the government and play major roles in formulating India's climate policy and NDCs behind the scenes. In recent years, independent research institutes in India have helped the Indian government formulate policies to improve the country's resilience to the impacts of climate change, and to build capacity to tackle climaterelated disasters. In addition to supporting measures to implement India's NDC targets, independent think tanks monitor and report on the progress of its climate policies. The Indian Network on Climate Change Assessment, a network of 127 institutions, was established to share knowledge of and work collaboratively on climate change issues (Government of India 2015).

Recognizing the value of think tanks, the Ministry of Environment, Forestry, and Climate Change established the Climate Modelling Forum, made up of several independent research and academic institutions which agreed to provide their inputs for a comparative study of independent modeling results (Ministry of Environment, Forests, and Climate Change 2009). The National Institution for Transforming India (NITI) Aayog (formerly the Planning Commission of India) also started a joint working group for integrated energy modeling. Over the years, the Energy Division of NITI Aayog has collaborated with other think tanks to formulate proposals for India's NDCs that provide sustainable pathways for the country.

Although independent research institutes play major roles in advising the government on target setting through qualitative and quantitative studies, the government retains its role as the ultimate decision maker. The government has tended to choose the least ambitious targets from the range of emissions intensity targets proposed by independent research institutes. However, it is clear that insights from these institutes help provide the foundation upon which the government formulates its NDCs. 


\section{Energy Access and Energy Security}

nergy access, energy security and climate change policies are interrelated issues in India. Despite recent government claims that nearly the whole country has access to electricity, approximately 30 percent of the Indian population lacks access, and almost 70 percent still rely on traditional biomass for cooking (Government of India 2015). Furthermore, India imports 82.1 percent of its crude oil demand and 44.4 percent of its natural gas demand. In order to meet the country's energy demand, it allocates a significant proportion of its foreign reserves to cover the cost of importing crude oil and liquefied natural gas (Ministry of Petroleum and Natural Gas 2018). India's climate change policy challenges are closely linked with its need to address energy poverty, access to electricity and its high energy-import dependency.

As Figure 3 illustrates, India's electricity sector is dominated by fossil fuels, mostly coal. As of 2018, coal has an installed capacity of $197 \mathrm{GW}$ (57 percent) out of a total of $344 \mathrm{GW}$. Renewable energy (excluding large hydroelectric power [hydro]) accounts for 20 percent of its total generation capacity.

Figure 3. The share of India's installed electricity capacity (GW), 2018.

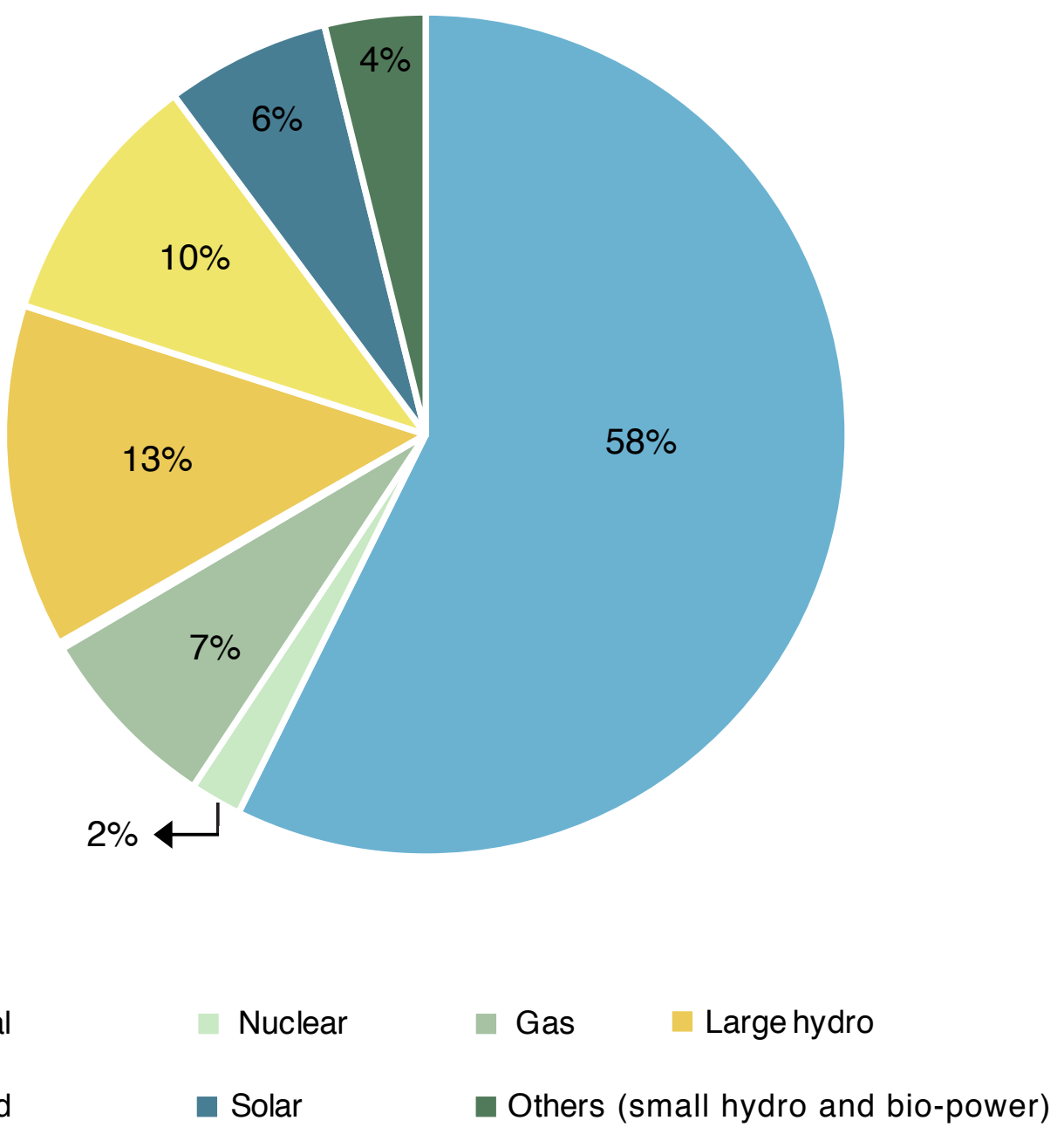

Source: MOSPI, MNRE, KAPSARC analysis. 
To reduce coal imports, the Indian government has set a domestic coal production target of 1.5 billion tonnes by 2020. To achieve this target, coal production capacity will have to almost triple by 2020 . The government plans to achieve 175 GW of installed renewables capacity by 2022 , including $100 \mathrm{GW}$ of solar, a fivefold increase from its previous target. Both renewable and coal-based plants have specific functions within the country's energy sector, with coal power plants continuing to play a critical role in providing baseload power. The intermittency of renewable generation makes it challenging to replace coal plants entirely with renewable energy. To make renewable energy a viable option, India needs to invest heavily in battery technology. For these reasons, Indian energy experts believe that coal will remain the dominant fuel for the future, though the energy mix will change with the share of renewables increasing and the share of coal falling.

According to its NDC commitment, India needs to generate 40 percent of its power through non-fossil fuel sources by 2030 , which means it will need to install $340 \mathrm{GW}$ of non-fossil fuel energy sources. Recent statements suggest the government is planning up to $850 \mathrm{GW}$ of total power capacity (Sethi 2015). 


\section{Geopolitics}

ndia has wider geopolitical climate aspirations and wants to be a leader in international climate action. As recently as a decade ago, climate change was absent from India's political discourse. Today, the dialogue has evolved and the current administration seems to be serious in its effort to tackle climate change through its commitment to the Paris Agreement and the enactment of statelevel action plans. However, some experts suggest that India tends to be conservative in international commitments, keeping its targets low in order to overachieve them while leaving room for future economic growth.

Indian policymakers typically use other large emerging economies, notably China, as a benchmark when setting climate targets. The majority of experts interviewed believed that India's pledges and targets under the Paris Agreement are highly influenced by China's level of ambition. This is in part due to the similarities in the countries' economic and energyuse conditions, but it also reflects India's aspiration to pledge more ambitious targets than China.

Although both countries are trying to diversify their energy mix to more non-fossil fuel based sources, coal's share in the fuel mix remains the highest in both countries. With large populations and a big potential for future economic growth, both countries need to carefully assess the economic trade-offs when addressing climate change and setting their targets. In terms of global total $\mathrm{CO}_{2}$ emissions, China ranked first and India third, making the two

Figure 4. The growth of emissions and GDP in India and China.

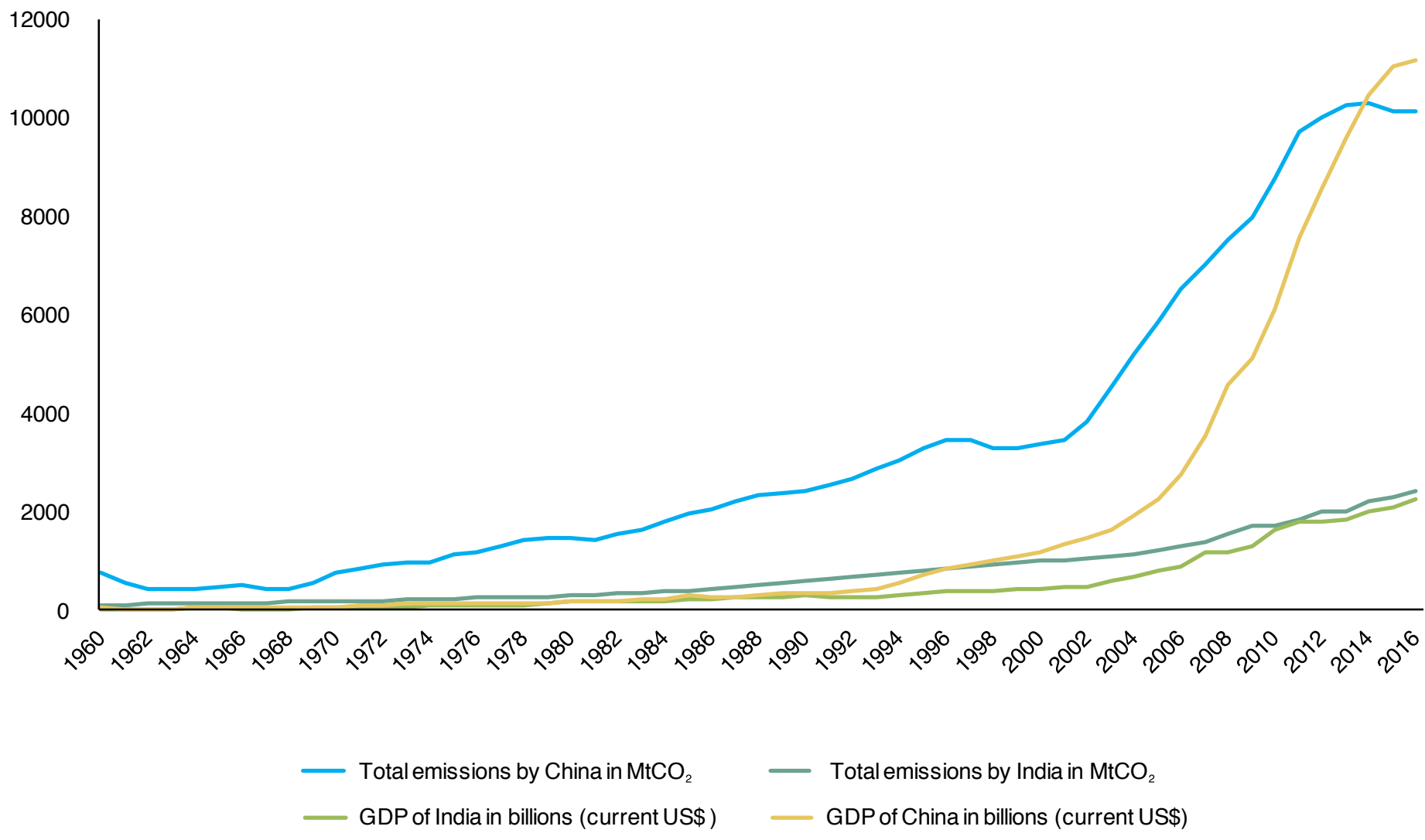

Source: U.S. Department of Energy, the World Bank, KAPSARC analysis. 
countries the highest emitters in Asia. With such high emissions, there is pressure on both countries to set more ambitious targets.

India is strongly motivated to address climate change, but emerging economies face competing policy priorities. For India, there is the challenge of balancing its role in international climate action while meeting its growing energy demand and aspirations for economic expansion. Energy security is crucial for India to sustain its growth, as growing demand for energy has raised its dependence on imports of conventional energy such as coal, crude oil and natural gas. Policymakers are aware of the benefits that can be obtained from increasing the share of non-fossil fuel sources in India's energy mix. These include reducing energy imports (mainly petroleum) and energy dependency on other countries, and benefiting from the financial support and technology transfer opportunities of the Green Climate Fund. The fund, considered the financial arm of the Paris Agreement, invests in mitigation and adaptation projects in emerging economies. Financing via this fund could not only accelerate the timeframe within which India can achieve its targets, but it could also relieve it of some of the financial burdens of implementing these projects on its own. 


\section{Socio-Economics Factors}

A

s one of the largest and fastest growing economies in the world, India has to cope with an array of challenges in order to sustain its economic development. The Indian government is trying to balance its response to international pressure to take action on climate change against its wish to sustain its economic growth. Although India is one of the most vulnerable countries to climate change impacts, the government has many other concerns, including poverty, air quality, access to electricity, health care and education. These other issues are of more immediate concern and, consequently, take priority in India's policy agenda.

India relies on climate-sensitive sectors like agriculture and forestry for the livelihood of its citizens, yet climate change is not one of its top priorities. Though the agricultural sector's contribution to India's GDP is only around 16 percent, 70 percent of Indians and 49 percent of the total workforce are either directly or indirectly dependent on it (Ministry of Finance 2017). However, agriculture is one of the sectors which is most vulnerable to the impacts of climate change, particularly the negative effects of climate change on crop yields and quality. These impacts consequently threaten food security and prices.

An issue of increasing priority for the Indian government is pollution, particularly urban air quality. According to the World Health Organization's global air pollution database, India has 14 of the 15 most polluted cities in the world (World Health Organization 2018), and around 70 percent of India's population are exposed to poor air quality. This poses major health risks and presents the government with a serious and urgent issue to address. The transportation sector and open burning of waste and crops are the main causes of air pollution in India. Recently, India's government announced plans to reduce air pollution, which should lead to a direct reduction in GHG emissions.

Another priority for the Indian government is to connect every household and public institution to the power grid. According to the International Energy Agency, around 240 million Indians did not have access to electricity in 2017. However, in April 2018, India's prime minister announced that the country's goal of electrifying all villages had been achieved ahead of its self-imposed deadline. Although all villages now have access to electricity, not every household is connected to the grid and that raises the issue of the reliability of electricity access. Further, many rural dwellers are still dependent on crop waste and animal residue for cooking and heating, which has negative effects on both the climate and human health. 


\section{Conclusion}

$\mathrm{T}$ The consensus among the experts interviewed in India is that the country will be at the forefront of international climate discussions and is inclined to pursue more ambitious NDCs. India's geopolitical ambitions in the climate change arena is balanced against its primary policy objectives to improve energy access within the country while supporting its economic growth. As a result, climate change is a secondary objective. Although India has developed coherent plans and policies to promote renewable energy and energy efficiency, it needs a strong institutional framework through which to implement these policies. India could also build its labor capacity and raise awareness of the risks posed by climate change.

The active participation of Indian states should help the country achieve its climate targets. Independent research institutes play a crucial role in shaping climate policy, and their efforts have led to more progressive climate change policies. Nevertheless, the challenge remains for India to develop policies that foster both sustainable development and climate change mitigation. 
Andrew, Robbie. 2018. "Why India's CO2 emissions grew strongly in 2017." Carbon Brief, March 28.

Council of the European Union. 2017. "EU-India Joint Statement On Clean Energy And Climate Change."

Government of India. 2015. "India's Intended Nationally Determined Contributions." UNFCCC.

Government of India. 2010. "https://www.unfccc.int/files/ meetings/cop_15/copenhagen_accord/application/pdf/ indiacphaccord_app2.pdf" www.unfccc.int Accessed June 6, 2018.

Ministry of Environment, Forests \& Climate Change. 2010. "Climate Change And India: A 4 X4 Assessment." Government of India.

Ministry of Environment, Forests, and Climate Change. 2009. "India's GHG Emissions Profile. Results of Five Climate Modelling Studies." Government of India.

Ministry of Finance. 2017. "Economic Survey 2017-18." Government of India.
Sethi, Nitin. 2015. "India's energy mix to have 40\% renewable sources by 2030." Business Standard, September 22, 2015. https://www.business-standard. com/article/economy-policy/india-s-energy-mix-to-have40-renewable-sources-by-2030-115092200057 1.html

Ministry of Petroleum and Natural Gas. 2018. "Annual Report 2017-18." Government of India.

Council of the European Union. 2017. "Eu-India Joint Statement On Clean Energy And Climate Change."

World Economic Forum. 2018. "Narendra Modi: These are the 3 greatest threats to civilization." January 23. Accessed June 11, 2018. https://www.weforum.org/ agenda/2018/01/narendra-modi-davos-these-are-the-3greatest-threats-to-civilization/

World Health Organization. 2018. "WHO Global Ambient Air Quality Database." 


\section{About the Team}

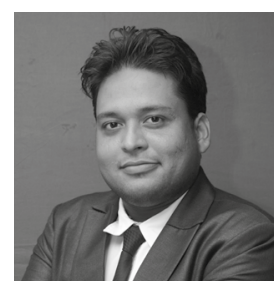

\section{Yagyavalk Bhatt}

Yagyavalk is a senior research analyst at KAPSARC, working on energy policies, with a focus on alternate energy, climate change, and automotive fuels. He previously worked as a researcher, providing sustainable development and decentralized renewable energy system solutions to the rural areas of north India. He holds an M. Tech degree in renewable energy from TERI University.

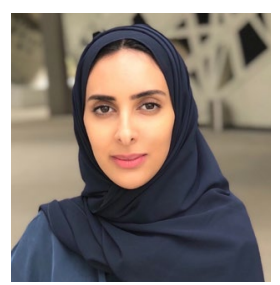

\section{Aljawhara AIQuayid}

AlJawhara is a research analyst in KAPSARC's Policy and Decision Science program with research interests in political economy, international affairs, finance and trade. She is currently working on evaluating the political feasibility of energy, environmental and economic policy options. Aljawhara holds a B.S. degree in business administration with a focus in finance from Alfaisal University.

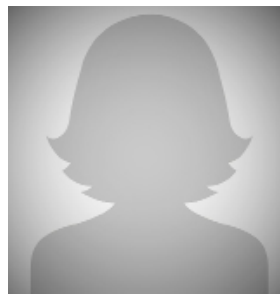

\section{Nourah Al Hosain}

Nourah is a research analyst in KAPSARC's Policy and Decision Science program. Her interests lie in data science and tool development. She is currently working with the KAPSARC Toolkit for Behavioral Analysis development team, and KAPSARC's Geographic Information Systems team.

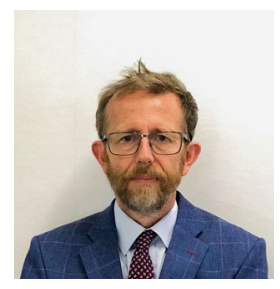

\section{Paul Mollet}

Paul is a research fellow in KAPSARC's Policy and Decision Sciences program. $\mathrm{He}$ is an analyst with over 25 years of experience covering international oil and energy markets. Paul has attended numerous OPEC meetings and written extensively about the oil industry in publications such as Platts Oilgram News, Argus Global Markets, and the Petroleum Economist.

\section{About the Project}

KAPSARC has developed the KAPSARC Toolkit for Behavioral Analysis (KTAB), an open source software platform, to model and analyze collective decision-making processes (CDMPs). KTAB is intended to be the standard platform for analyzing bargaining problems, generalized voting models and policy decision-making. We intend to use KTAB to assemble the building blocks for a broad class of CDMPs. Typical models in KTAB will draw on the insights of subject matter experts regarding decisionmakers and influencers in a methodical and consistent manner; helping researchers to identify feasible outcomes of CDMPs. 
ANAPSARC

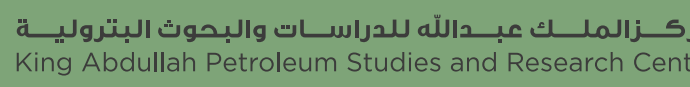

www.kapsarc.org 